

\title{
West Nusa Tenggara (NTB) Provincial Government's Efforts in Obtaining and Maintaining Unqualified Opinion by the Audit Board of Indonesia
}

\author{
Naufal Yazied \\ Ali Djamhuri \\ Lilik Purwanti \\ Universitas Brawijaya Malang \\ naufalyazied@gmail.com
}

\begin{abstract}
This research aimed to describe the efforts of NTB provincial government in obtaining and maintaining unqualified opinion by The Audit Board of Indonesia. This research used a qualitative approach. The results of this study indicated that in obtaining an unqualified opinion, the NTB provincial government did four stages of preparation; there were strengthening the leaders' commitment, developing policies in obtaining an unqualified opinion, following-up BPK-RI's findings, and organizing asset management. Meanwhile, to maintain the unqualified opinion, NTB provincial government did six stages, there were increasing the leaders' commitment, following up the findings of BPK-RI, establishing accounting policies and procedures, conducting internal control system, increasing the resources of local government officials, and developing the information system of financial and regional assets.
\end{abstract}

Keywords: BPK-RI, NTB, unqualified opinion

\section{INTRODUCTION}

Public accountability is a form of liability for the success or failure of bureaucratic mission in achieving predetermined goals and targets. It is performed through a medium of liability that carried out periodically. One of the government's media of liability to the public is a financial statement. A financial statement is a report on the financial management of government institutions. The accountability of the government's management can be measured through the supervision of government's activities both internally and externally.

Supervision is an activity performed by external parties, such as society and the Regional House of Representatives (DPRD), to supervise the performance of the government. The supervision can be in the form of approving, rejecting, and approving in certain condition based on the local regulations that will be stipulated as Local Regulations. Instruments that can be used for the supervision are the prevailing laws and predetermined budget plan. 
Government Regulation No. 79/2005 on The Guidance and Supervision of the local government's management states that supervision of government affairs in the regions is carried out by the Government Internal Supervisory Apparatus (APIP) in accordance with its functions and authorities. APIP consists of the Finance and Development Supervisory Board (BPKP), the Inspectorate General of Ministries, the Supervisory Unit of Non-Ministry Government Institutions, Provincial Inspectorate, and District or Municipal Inspectorate.

One of the units that conduct audits or inspection to the local government is the Regional Inspectorate. The Regulation of the Ministry of Home Affairs No 64 the Year 2007 states that the Regional Inspectorate has the main duty and the function to supervise the implementation of local government affairs, the implementation of guidance and affairs of the district and municipal government. The Provincial Inspectorate hold the position under the governor and be responsible to the governor, administratively it is secured by the provincial secretary, so the duties of the Inspectorate is the same as the internal auditor. An internal audit is an audit conducted by inspectorate units which are part of a supervised organization (Mardiasmo, 2005).

Government Regulation No 60 the Year 2008 regarding the Government Internal Control System states that APIP performs internal government control through audit, review, evaluation, monitoring, and other supervised activities. The provincial inspectorate is a functional supervisory apparatus that holds position under and be responsible to the governor who reviews the provincial government's financial statements before being conveyed to the Supreme Audit Board. The district or municipal inspectorate is a functional supervisory apparatus that holds position under and be responsible to the regent or a mayor who reviews the financial statements before it is submitted to BPK.

The duty of West Nusa Tenggara (NTB) Provincial Inspectorate, as stipulated in Regional Regulation Number 8 the year 2008, is to supervise the implementation of government affairs in the Provincial Region, the implementation of the guidance and affairs in the district or municipal government. In performing those duties, the West Nusa Tenggara (NTB) Provincial Inspectorate also carries out the functions of supervisory program planning, policy formulation, and facilitation of supervision, examination, investigation, testing, and assessment of supervision's task, control and evaluation of supervision's task, and other duties imposed by the Governor.

The Government Accountability Office (GAO) explains that the quality of the audit highly depends on the level of professional compliance standards and contractual ties during the conduct of the audit (Lowensohn, et al., 2005). Elfarini (2007) concludes that the same opinion was expressed by the Indonesian Institute of Accountants (IAI) that audits conducted 
by auditors are said to be qualified if they meet auditing standards and quality control standards. Efendy (2010) further explains that qualified audits are audits that can be followed up by the audit. This quality must be built from the beginning of the audit to the reporting and giving a recommendation. Thus, the indicators used to measure the quality of audit include the quality of the process, whether the audit is done meticulously according to the procedure while continuing to maintain skepticism.

This study examines the efforts undertaken by the NTB Provincial Government in obtaining and maintaining an unqualified opinion from 2011 to 2015. The unqualified opinion indicates that the LKPD, that is arranged by the NTB Provincial Government for the Fiscal Year 2015, is in accordance with SAP, adequately disclosed, and there is no non-compliance that affects the material, and has arranged and designed the elements of the Internal Control Standard (SPI), namely the control environment, risk assessment, control activities, information, communication, and monitoring. It is also supported by the Head of BPK RI, Harry Azhar Aziz who stated that the Provincial Government of NTB is the only province in Indonesia, which won the unqualified opinion title in the local government financial statement four times in a row (beritasatu.com, 2015).

By applying a qualitative approach, this research would like to know the efforts made by the NTB Provincial Government in obtaining and maintaining the unqualified opinion. This research is expected to provide an overview of NTB Provincial Government's side in obtaining and maintaining the unqualified opinion.

\section{LITERATURE REVIEW AND HYPOTHESES}

New Public Management (NPM) is a new theory of public management which assumes that the practices of private sector management are better than the practices of public sector management. NPM is a new public/government management concept, applying the practices of the private sector to the public sector to create efficiency and effectiveness of local government performance in constructing society's welfare. The main idea proposed in these concepts states that the public sector must be market-oriented so that there is a great cost of efficiency for the government.

Indrawati (2010), according to Osborne and Gaebler offers 10 (ten) principles of selfemployed government, they are catalyst governance, community-owned governance, competitive governance, mission-driven governance, results-oriented governance, customeroriented governance, entrepreneurial governance, anticipatory governance, decentralized governance, and market-oriented governance. 
According to (Hood, 1991) in Indrawati (2010) there are seven characteristics of NPM, namely: professional management in the public sector, standards and performance measures, putting greater emphasis on the control of outputs and outcomes, splitting the working units in the public sector, creating competition in the public sector, adopting management styles in the business sector into the public sector, and emphasizing on discipline and greater savings using resources.

The audit opinion is a report given by a registered auditor stating that the inspection has been conducted in accordance with the norm or the rules. It is followed by opinions regarding the fairness of the financial statements examined (Tobing, 2004). According to the Law of Indonesia Number 15 the Year 2004 regarding the Audit of State Financial Management and Accountability, states that there are four types of opinions that can be given by BPK-RI, namely: unqualified opinion, a fair opinion with exceptions, unfair opinion, and statement refused to give an opinion.

The House of Representatives has shown seriousness in accountability of public sector organizations to realize Good Governance by stipulating legislation in the field of state finance covering Law Number 17 Year 2003 regarding State Finance, Law Number 1 Year 2004 on State Treasury, and Law Number 15 Year 2004 on the Audit of State Financial Management and Accountability along with its supporting regulations to improve the management, report, accountability, and audit of the government's financial management at both the central and regional levels.

The government keeps updating existing laws and regulations to fulfill the demand for state finances to be managed in an orderly, efficiently, economically, and in accordance with the standards. These regulations include Government Regulation (PP) No. 24 of 2005 on Government Accounting Standards (SAP). Based on PP. 24 of 2005 on Governmental Accounting Standards, "Government Accounting Standards are the accounting principles adopted in preparing and presenting government financial statements". A SAP is applied in the scope of government, namely central government, local government, and organizational units in central or local government. The Government also stipulated Government Regulation Number 58 the Year 2005 regarding Regional Financial Management, and Government Regulation Number 8 the Year 2006 regarding Financial Reporting and Performance of Government Agencies. The various laws and regulations are expected to increase public accountability that is a necessity in the implementation of regional autonomy. 


\section{METHODS}

This study used a qualitative approach with a case study research model under postpositivist paradigm. A qualitative research method is employed to explore descriptive data from research subjects to be used in understanding the meaning of an event that occurs naturally (Moleong, 2009). A qualitative research aims to obtain a complete picture of something that happens. In conducting qualitative research the researcher must follow the correct procedure, method, and technique in obtaining natural data, analyze and perform the interpretation to produce an accurate conclusion.

In this study, case study model was chosen because the researcher wanted to observe the effort of NTB Provincial Government in obtaining and maintaining the unqualified opinion which is given by BPK. The case study provides a detailed picture of the analysis results of the NTB Provincial Government's role as an audit in presenting LKPD to obtain an unqualified opinion given by the CPC and also to get a clear description and depth about the strategy and the work done by the NTB provincial government to maintain the unqualified opinion during five consecutive years. In order to gain an adequate understanding of the unqualified opinion for five consecutive years (2011-2015), the researcher needs some informants who understand the data, information, and facts around the issues studied. The informants come from several parties. The first informant is the inspectorate of NTB Province that conducts the supervision on the implementation of government affairs in the Provincial region, implementation of guidance and affairs in regencies/municipalities. In carrying out the above mentioned tasks, the West Nusa Tenggara Provincial Inspectorate carries out the functions of supervisory program planning, policy formulation and facilitation of supervision, examination, investigation, testing and assessment of tasks of supervision, control and evaluation of supervisory duty implementation, other tasks assigned by the Governor in accordance with the duties and functions. Second informant is the Provincial Finance and Asset Management Board of NTB Provincial Assembly that is responsible for assisting the governor in implementing the regional policy in the field of financial and asset management, preparing the financial statements of NTB Provincial government, carrying out the function of management of regional assets in an orderly and optimal manner to increase the income of regional.

\section{RESULTS AND DISCUSSION}

\section{Vision and Mission of West Nusa Tenggara Province}

The vision of West Nusa Tenggara Province that wants to be realized in the period 20132018 is "NTB Yang Beriman, Berbudaya, Sejahtera, and Berdayasanya". 
NTB Provincial Government has four missions as follows, the first mission is to accelerate the realization of a society that characterized through religious stabilization, Pancasila actualization as the nation's ideology and cultural endurance. This first mission aims to improve the dignity of society based on the religious and cultural values of the region.

The second mission is to improve the quality of competent human resources through quality, affordable and gender equitable education, health, and welfare services. This mission aims to improve the quality of human resources, the realization of an intelligent and skilled society that have an insight of science and technology, and the realization of a healthy and prosperous society.

The third mission is to increase regional competitive advantage by developing tourism, agro-industry, and a creative economy based on culture and local resources as well as science and technology. This mission aims to improve people's living standards and regional competitiveness, the realization of a reliable tourist destination.

The fourth mission is to continue the acceleration of infrastructure development and interregional connectivity based on spatial and environment. This fourth mission aims to improve the availability of infrastructure that supports the economy and optimize sustainable development.

\section{Opinion on Financial Report of NTB Provincial Government}

During the period from 2010 to 2015, the acquisition of an NTB Provincial LKPD audit opinion shows an upward trend as shown in the Table as follows:

Table 1. The progress of the Audit's opinion LKPD Pemprov NTB

\begin{tabular}{cc}
\hline Tahun & Audit's Opinion \\
\hline $\mathbf{2 0 1 0}$ & Disclaimer \\
$\mathbf{2 0 1 1}$ & Unqualified \\
$\mathbf{2 0 1 2}$ & Unqualified \\
$\mathbf{2 0 1 3}$ & Unqualified \\
$\mathbf{2 0 1 4}$ & Unqualified \\
$\mathbf{2 0 1 5}$ & Unqualified \\
\hline
\end{tabular}

source :www.mataram.bpk.go.id

From the table above, it was found out that the results of the LKDP examination in 2010 got a disclaimer opinion. An unqualified opinion is issued by the CPC if the financial statements are considered to provide information free of material misstatement. If the financial statements are given this type of opinion, it means that the auditor believes that the company/government is deemed to have generally accepted accounting principles, and even if there is a mistake, the error is considered immaterial and has no significant effect on decision making. 
From the same table, it was found out that since 2011 until the time of this research conducted, the opinion of BPK RI in LKPD NTB Provincial Government always gets the unqualified opinion. The results showed the efforts of the NTB Provincial Government in getting and maintain the unqualified opinian.

\section{Preparation in getting unqualified opinion}

According to the Supreme Audit Agency, opinion is the professional statement of the auditor on the fairness of financial information presented in the financial statements, based on four criteria namely compliance with government accounting standards, adequate disclosures, compliance with statutory regulations, and effectiveness of internal control systems (bpk.go.id). BPK's opinion can be one of the benchmarks to assess whether the local government's financial management is transparent and accountable or not.

In 2011, the NTB Provincial Government received a disclaimer opinion from BPK RI Representative of NTB Province related to Local Government Financial Report for the fiscal year 2010. Management error was the main factor causing NTB Provincial Government to get disclaimer opinion. Based on the Audit Result Report (LHP) of BPK-RI, on LKPD NTB Provincial Government for Fiscal Year 2010 Number: 193.A / S / XIX.MTR / 05/2011 dated May 27, 2011, there were differences in the report of fixed asset value between the Finance Bureau and the Public Bureau of Rp. 16.57 billion. As stated by Head of Accounting Division of BPKAD Prov. NTB (Mr. Azhar):

"So by the year 2010 we got the disclaimer, we were very weak in the management of regional assets. There was a considerable difference in asset value between the General Bureau as the regional asset manager and the Finance Bureau which caused LKPD Prov. NTB got disclaimer opinion. The difference was about 16 billion. The value of the assets between the Public Bureau and the Financial Bureau should be the same. "

Through the above explanation, it was revealed that disclaimer opinion obtained by NTB provincial government in the 2010 fiscal year was due to differences in the recording of asset values between the Finance Bureau and the Public Bureau. NTB Provincial Government could not materially explain the differences in the value of fixed assets between the Finance Bureau and the Public Bureau as a regional asset manager so that BPK could not perform adequate inspection procedures to obtain confidence in the value of the property and equipment. BPK also found a heavily damaged asset of Rp. 3.40 billion at the DPRD Secretariat because it was not listed in the inventory book and was unknown to its existence. This prevents BPK from conducting adequate inspection procedures to convince the unknown asset value. 
Due to the disclaimer opinion, NTB Provincial Government made several preparations in order to improve the quality of LKPD for the next fiscal year. This was done by stipulating regional regulations related to accounting policies and accounting procedures system, updating and improving the information system of regional financial management and regional goods management, then conducting training for financial managers and managers of regional assets, training for the staffs in all SKPD, management of local assets, and structuring of local assets. Therefore, in order to realize the above activities, it is necessary to have special preparation, strategy, and a serious effort from NTB Provincial Government so that their financial report will not be disclaimed again. Here are some strategies were undertaken by the NTB Provincial Government to obtain an unqualified opinion.

To be able to obtain an unqualified opinion from the BPK on the financial statements, the important thing is a commitment from local leaders. Local leaders are not only Governors but also members of DPRD and Head of SKPD. Commitment from the leader is very important because local leaders are decision makers, in the hands of those policies, important regional regulations are made. The next step instructs the head of the SKPD to create an integrity pact on its commitment and support to the acquisition of a unqualified opinion (Suwanda, 2013). The commitment from the regional secretary and all the head of SKDP is also needed. The Integrity pact was made to prove the commitment of all the head of SKDP. Like what has been said by the former secretary of Prov. NTB inspector (Ibu Maemunah):

"At the meeting with all SKPD at the Governor's office, we are required by the Governor to commit seriously to follow up the findings of BPK. Furthermore, the Governor also gave directions to trace all of our assets that are not clearly established and asked to reconcile records of all the assets we have, because of the issue of this asset that makes us got disclaimer ".

Head of SKPD creates an integrity pact to implement good financial governance and regional assets in order to obtain unqualified opinion. NTB provincial government committed to taking responsibility for solving the asset problem in order to obtain unqualified opinion. Last but not least is the mutual commitment of financial managers, financial reporters, regional asset managers, auditors of the Inspectorate of NTB Provincial Government, as they are technical personnel working on the preparation of financial statements, the preparation of reports on regional assets, and reviewing the financial statements. has been compiled by all levels of the provincial scope.

The main factors that make LKPD of NTB provincial governement in 2010 received disclaimer opinion is the absence of a special policy that regulates the management of finance and regional assets. This makes the financial statements of SKPD and LKPD NTB Provincial 
Government which is a consolidation report of all SKPD does not have clear guidance in many aspects in the field of financial management and regional assets, such as depreciation and so forth there is no policy regulating financial governance and assets which causes LKPD NTB Provincial Government get disclaimer opinion. This was revealed by Mr. Ainudin, Superintendent IV. Here are excerpts of the interview:

"One factor that makes our LKPD got disclaimer at the time was the absence of a specific policy on financial management and local assets. At that time, the Governor immediately made a policy regarding all our weaknesses in the management and security of local assets. After the policy is established, the Inspectorate as APIP oversees all SKPD to implement the policy ".

So, at that time the Governor of NTB immediately made the policy. The essence of managing financial and local assets begins with accurately identifying the current conditions, then identifying the regulation that is the hope and goal to be achieved (John and Setiawan, 2009).

In the Report of Examination Result (LHP) of BPK-RI on LKPD NTB Provincial Government for Fiscal Year 2010 Number: 193.A / S / XIX.MTR / 05/2011 dated 27 May 2011 one of the causes that make Provincial Government of NTB got disclaimer opinion is the problem of asset value report. It was found the differences in fixed asset value between the Bureau of Treasury and the Public Bureau is Rp.16.57 billion and BPK RI also found heavily damaged assets of Rp. 3.40 billion at the DPRD Secretariat because it is not listed in the inventory book and is unknown to its existence. It can be concluded that the disclaimer from BPK RI to LKPD NTB Provincial Budget Year 2010 is due to asset problem. The steps taken by the NTB Provincial Government on these findings are by structuring and managing assets. One of the efforts undertaken in the asset structuring activities is asset reconciliation and all NTB Provincial Government assets are reclassified according to the condition of the assets.

Structuring a Regional Property Assets consists of movable assets and immovable assets. In another aspect, this government asset can act as a guarantee of development in the region. In order to realize the orderly administration of the management, the NTB provincial government should regulate the working guidelines, for it has been issued on Regulation of the Minister of Home Affairs 17 of 2007 on Technical Guidelines for Management of Regional Property. In the Regulation of the Minister of Home Affairs referred to as the Regional Property are all items purchased or obtained at the expense of the Regional Revenue and Expense Budget or any other legal acquisition. NTB Provincial Government arranges the documents of regional assets and structurize documents that belonging to the regional to secure the assets from the aspect of regional administration. Meanwhile, asset security aims to keep the regional assets do not 
change hands illegally and facilitate the local government in managing further. Management of regional property aims to make regional assets can give benefits. At the time of inquiring one of the Ditor Inspektorat, NTB provincial government conducts a regional census of asset inventory by involving all SKPD and Inspectorate. To support the activities, NTB provincial government issued Governor Regulation No. 2 of 2010 on the procedures for the implementation of the use, utilization, deletion, and alienation of regional property. These activities are carried out in order to ensure that the assets of the region are recorded and safeguarded so as to provide asset value for the region. Maintenance is an activity or action undertaken so that all goods owned by the area are always in good condition and ready to be used in an efficient and effective manner, while security is the activity of control activities in the management of local property in the form of physical, administrative and legal action.

\section{Strategy to Maintain Unqualified opinion}

A regional financial management is the overall activity of the regional finance manager in accordance with its position and authority, which includes planning, implementation, monitoring, and accountability. Regional audits include an examination of local financial management and audit of local financial responsibilities. In order to maintain the unqualified opinion from the BPK on the financial reports of NTB provincial government, the main thing is the commitment of the Regional Head (Governor). The commitment of the Governor is very important because the Governor is the decision maker, in the hands of the policy, and the important regional regulations are made.

Maintaining an unqualified opinion is not as easy as turning a palm of a hand, but it must be realized through a process based on the good input, good process, and good output. These three aspects must be integrated and sustainable as the foundation of good financial reporting system, including the commitment of regional leaders and staffs. (Kurniawan, 2011). After the commitment of the Governor which is the result of joint coordination with the members of DPRD, furthermore necessary to maintain the opinion of the PAP is the commitment of the Regional Secretary, the Assistant Secretary of Regions and of course all Head of SKPD within the local government. One of the proofs of the commitment statement by the head of SKPD is making integrity pact. Head of SKPD creates an integrity pact to implement good financial governance and regional assets in order to obtain unqualified opinion. As Inspector said (Mr. Ibnu):

"So, every year we create some kind of contract of work/integrity pact on the commitment to maintain the opinion of the PAPs for the Provincial Government of 
NTB's Financial Statements. So the contract is signed by the Governor and all SKPD heads. The work contracts made are used to ensure that all SKPD heads are responsible and committed to continuously improve the quality of their financial statements ".

Based on the interviews of Mr. Inspector Prov. NTB revealed that all SKPD Heads committed being responsible for maintaining the opinion of the unqualified opinion. Last but not least is the mutual commitment of financial managers, financial reporters, local asset managers, and inspectorate auditors to the NTB provincial government. Since they are technical personnel that work on the preparation of financial statements and review the financial statements that have been prepared by the NTB provincial government.

BPK conducts audits on local financial management and accountability. The results of the audit of the management and financial responsibilities of the region are poured into the Report on Examination Result (LHP). The LHP contains recommendations or advice from the examiner based on the results of the examination, addressed to persons and/or bodies authorized to take action or remedy. The commitment of the regional head to follow up on the recommendations and findings of the result of the examination based on the law number 15 of 2004, article 20 paragraph 1-3 is stated: Officials are required to follow up the recommendations in the inspection report, Official shall be required to provide answers or explanations to BPK on follow- report on the results of the examination, the answer or explanation of the follow-up on the recommendation in the report of inspection result shall be submitted to BPK no later than 60 days after the report of the examination result is received. In article 20 paragraph (1) it is also stated that follow-up on the recommendation may be the implementation of whole or part of the recommendation, in part or all of the case.

Recommendations cannot be implemented; officials are required to provide valid reasons. To support the Inspectorate in following up the findings of BPK-RI, NTB provincial government issued Governor Regulation No. 5 of 2014 on Monitoring Guidelines for Followup Supervision / Supervision Results of BPK-RI and APIP. In following up the findings of LHP BPK-RI, the Governor shall also commit to monitoring the results of those activities. Monitoring follows up finding (TLHP) is conducted by the governor by assigning an inspectorate unit to solve TLHP. The inspectorate has written mechanism and procedure to follow up the findings or LHP internal and external recommendation. The inspectorate also regularly deliver the development of TLHP to the governor, DRPR, and BPK. Governor monitor and follow up the findings to prevent the same finding from the previous year. The benefit of the BPK-RI inspection relies on the effectiveness of settlement conducted by NTB government. 
The first attachment of the Minister of Home Affairs regulation No 64 the year 2013 stated that the accounting policy is an important instrument in implementing accounting accrual. So, all the head of local government can create a regulation that sets the accounting policy based on the SAP elements which then can be developed in term of recognition, measurement, and disclosure. There are two steps in creating accounting policy, they are the arrangement of accounting policy and arrangement of accounting policy in the financial statement. The government can use Statement of Government Accounting Standard (PSAP) in the first attachment of PP No. 71 the year 2010 as the primary reference in arranging accounting policy. As well as the leaders' commitment, the provisions of an organization have been explained in the second principal of NPM. The second principal talks about the explicit standard and measures of performance. The assertive and measurable standard of the organization performance include clarification of purpose, target, and indicators of success.

The regulation of NTB government No 53 the year 2015 about the accounting policy is a concrete form of the implementation of the NPM principal because it is the assertive and measurable guideline of the government in achieving the purpose through the clear indicator. One of the purposes that will be achieved by NTB government is producing LKDP to obtain unqualified opinion

The government internal control system was designed to give an assurance on the reliability of the financial statement, the effectiveness and efficiency of operations, and the obedience of the law and regulation. To realize that, the government published PP No 60 the year 2008 about government internal control system. Based on the regulation, SPI is the integration process in a regular activity conducted by the leaders and all the staff to give an assurance on the reliability of the financial statement, the effectiveness and efficiency of operations, and the obedience of the law and regulation. PP No 60 the year 2008 emphasized to combat corruption and nepotism $(\mathrm{KKN})$ in every aspect. As explained that SPIP was background by the organizing activities in government institute, start form planning, execution, guidance, and accountability that should be conducted orderly, controlled, effective, and efficient.

NTB government has published the Regulation of Governor No 4 the year 2011 about the government internal control system as the law and guideline in implementing the government internal control system. NTB government has also formed the task force of government internal control system in provincial level. The success in getting unqualified opinion did not mean that the government internal control system is perfect. The government internal control system still needed some improvement, it was proven by the finding of LHP that made by BPK. If SKDP 
did maximum control toward the financial and regional assets, the value findings would be minimalized. Regardless of the findings, the implementation of PP No 60 the year 2008 in government is the form of government commitment to create good governance that is supported by integrated bureaucracy.

The lack of socialization and understanding of the government internal control system caused the difficulty in implementing this regulation. To evaluate the financial statement in next year, BPK will evaluate all the factor in implementing government internal control system. There is some strategy to guide the implementation of government internal control system, they are the arrangement of technical guidelines, the education and training, the guiding and consultation, and the enhancement of auditor APIP's competence.

One of the challenges in enhancing human resources is the discrepancy of knowledge and skill between APIP in managing the financial and regional assets. Therefore, the NTB government has been conducting technical and material training and socialization in implementing SAP accrual to all of the staff that responsible for managing financial statement. This training was conducted by NTB government and BPKP. NTB government also conducted individual training. NTB government sent the staff to join the training that is conducted by the external parties. The training is one of the strategies for enhancing the human resources. Besides, the number of the human resources should also be increased, so it can optimize the implementation of SAP accrual.

As stated by the former vice governor (Mr. Badrul Munir, 2012) one of the key factors in the success of maintaining unqualified opinion is the capability of information and communication technology. Since every reporting entity has accountant entity, it is needed to provide reliable information and communication technology. The next step in implementing SAP accrual is creating Management Information System of Regional Financial and Management Information System of Regional Assets. In NTB Governor regulation No 53 the Year 2015 about the accounting policy, stated that

In the Regulation of NTB Governor No 53 the Year 2015 about accounting policy stated that as a form of responsibility in implementing APBD, the NTB government financial statement uses SAP accrual. Related to that point, one of the preparation is creating accounting applications based on the accrual. This is the quote of the interview from The Head of Accounting BPKAD (Mr. Azhar) about the special policy on the creation of SIMDA:

"the thing that is connected to special policy is also connected to the utilization of IT.

To utilize IT NTB governor has had one policy that is Sistem Informasi Manajemen Keuangan Daerah (SIMDA)/ Management Infomation System of Regional Financial. 
All this time, we have been using SIMDA, but it is still based on a cash system, as we called blue SIMDA. The new development is green SIMDA, it is based on accrual system."

The same thing also delivered by the head of regional treasury fun, BPKAD (Mr. Syamsudar):

"The preparation done by NTB government in implementing SAP accrual is by cooperating with BPKP in creating financial SIMDA set the grand design of management database system. The parties that involve are not the only accountant, but also IT. The form of assistance is evaluating financial SIMDA developed by BPKP. Financial SIMDA that is developed by BPKP still need improvement during the implementation."

Based on the above statement, the NTB provincial government cooperated with BPKP to create financial SIMDA based on accrual. As has been said by the informant that the NTB provincial government used a different application with other local government since NTB provincial government used application based on accruals for financial SIMDA and regional assets SIMDA. In implementing SAP accruals, the NTB provincial government faced some complex challenge that was SAP accrual is a new thing that should be learned by financial managers, financial report compilers, and auditing in NTB provincial government.

\section{CONCLUSION}

There are four steps that are conducted by the NTB provincial government in getting an unqualified opinion, namely: the commitment of the leaders, the policies in getting unqualified opinion, structurize the government assets, and follow up the findings of BPK RI. The commitment of the leaders, in this case, is the responsibility of NTB Governor, Inspectorate, BPKAD, SKPD, and all the staff in preparing the financial statement and getting unqualified opinion. The second step is reconciliation the assets, inverse the assets, and re-clarification of the asset's condition. The third step is establishing a policy about the vision and mission that will be achieved by the NTB government in facing the BPK inspection. After that, the government recording and securing the regional assets structurally, so the report of the assets can be reported correctly.

After getting unqualified opinion, there are six steps in maintaining the unqualified opinion. Those steps are the commitment of the leaders; follow up the findings of BPK, the regulation of local government about the accounting policy and accounting procedural system, internal control system, the escalation of human resources, and the strategy on the expansion of the financial information system and regional assets. 
In the process of collecting data, the researcher got some limitation which was not the main problem in constructing the result of the study. The first limitation was the difficulty in obtaining a review of the interview from BPK RI. It happened because the parties involved were busy conducting an inspection in district or municipal, so the parties were difficult to be met. However, the data needed by the researcher could be obtained through LHP BPK RI. Since this study was conducted based on the track record of the fiscal year 2010 to 2015, the second limitation was that the primary respondents has moved to another SKDP and has retired

The significant implication of this study is NTB provincial government will more understand every step to be conducted in obtaining and maintaining unqualified opinion. The efforts in obtaining an unqualified opinion do not detach from the support of local government, the policy of obtaining an unqualified opinion, the result of BPK's audit in the previous year, and management of regional assets. While there is some strategy in maintaining unqualified opinion, namely: strengthening the leaders' commitment, the regulation in managing the accounting policy, the enhancement of internal control system, the enhancement of human resources, and the expansion of financial accounting system and regional assets.

After obtaining and maintaining unqualified opinion with various strategies, NTB provincial government will be known as a local government that has good performance, good achievement of economic growth and accountable management of financial and regional assets. The NTB provincial government will be encouraged to prepare the next financial statement as accountable as possible. Therefore, every strategy in obtaining and maintaining the unqualified opinion should be conducted maximally.

By seeing the limitation in this study, the future researcher is expected to excavate the information from BPK to get other perception from external parties towards LKPD. The future researcher also can excavate the problem of LKPD with other local government because every local government has different problems in constructing and reporting financial statement.

\section{REFERENCES}

Beritasatu. (2015). BPK Sebut NTB Provinsi Peraih unqualified opinion Terbanyak. Retrived 10 April 2016 from http://www.beritasatu.com/ekonomi/301845-bpk-sebut-ntbprovinsi-peraih-unqualified opinion-terbanyak.html

BPK. (2011). Opini unqualified opinion Tidak Menjamin Tidak Ada Korupisi. Retrived 2 Mei 2016 from http://www.bpk.go.id/news/opini-unqualified opinion-tidak-menjamintidak-ada-korupsi 
Efendy, M.T. (2010). Pengaruh Kompetensi, Independensi, Dan Motivasi Terhadap Kualitas Audit Aparat Inspektorat Dalam Pengawasan Keuangan Daerah (Studi Empiris Pada Pemerintah Kota Gorontalo). Tesis. Program Pasca Sarjana Magister Akuntansi Universitas Diponegoro.

Elfarini, E.C. (2007). Pengaruh Kompetensi Dan Independensi Auditor Terhadap Kualitas Audit (Studi Empiris Pada Kantor Akuntan Publik Di Jawa Tengah). Fakultas Ekonomi Universitas Negeri Semarang.

Indrawati, N. (2010). Penyusunan Anggaran dalam Era New Public Management: Implementasinya di Indonesia. Jurnal Riset Akuntansi dan Bisnis. Vol. 10 No. 2, September. Fakultas Ekonomi. Universitas Muhammadiyah Sumatera Utara.

John, Y. M. and D. Setiawan. (2009). Kiat Memahami Pemeriksaan Laporan Keuangan Pemerintah Daerah Di Indonesia. Edisi Pertama. Jakarta: Gramedia.

Kurniawan, S. (2011). BPK RI Beri Opini WDP terhadap LKPD Enam Pemerintah Kabupaten/Kota di Jabar. Siaran Pers Penyerahan LHP-LKPD TA 2010. Juli, 2011. Bandung.

Laporan Hasil Pemeriksaan BPK RI Atas Laporan Keuangan Pemerintah Daerah Provinsi Nusa Tenggara Barat Tahun Anggaran 2010.

Lowensohn S, Laurence E.J, and Randal J.E. (2005). Auditor Specialization and Perceived Audit Quality, Auditee Satisfaction and Audit Fees In The Local Government Audit Market. Department Of Accounting Colorado State University.

Mardiasmo. (2005). Akuntansi Sektor Publik. Edisi 2. Yogyakarta: Penerbit Andi.

Moleong, L. J. (2007). Metodologi Penelitian Kualitatif. Edisi Revisi. Cetakan keduapuluh empat. Bandung: Penerbit PT. Remaja Rosdakarya.

Peraturan Gubernur Provinsi Nusa Tenggara Barat Nomor 2 Tahun 2010 tentang Tata Cara Pelaksanaan Penggunaan, Pemanfaatan, Penghapusan, dan Pemindahtanganan Barang Milik Daerah.

Peraturan Gubernur Provinsi Nusa Tenggara Barat Nomor 4 Tahun 2011 tentang Sistem Pengendalian Intern Pemerintah di Lingkungan Pemerintah Provinsi Nusa Tenggara Barat.

Peraturan Gubernur Provinsi Nusa Tenggara Barat Nomor 5 Tahun 2014 tentang Pedoman Pemantauan Tindak Lanjut Hasil Pengawasan/Pemeriksaan BPK RI dan APIP.

Peraturan Gubernur Provinsi Nusa Tenggara Barat Nomor 53 Tahun 2015 tentang Kebijakan Akuntansi Pemerintah Provinsi Nusa Tenggara Barat. 
N. Yazied, A. Djamhuri, L. Purwanti / Journal of Accounting and Business Education, 2 (2), March 2018

Peraturan Pemerintah Republik Indonesia Nomor 79 Tahun 2005 tentang Pedoman Pembinaan dan Pengawasan Penyelenggaraan Pemerintah Daerah.

Peraturan Pemerintah Republik Indonesia Nomor 60 Tahun 2008 tentang Sistem Pengendalian Intern Pemerintah.

Peraturan Pemerintah Republik Indonesia Nomor 24 Tahun 2005 tentang Standar Akuntansi Pemerintah.

Peraturan Pemerintah Republik Indonesia Nomor 58 Tahun 2005 tentang Pengelolaan Keuangan Daerah.

Peraturan Pemerintah Republik Indonesia Nomor 8 Tahun 2006 tentang Pelaporan Keuangan dan Kinerja Instansi Pemerintah.

Peraturan Pemerintah Republik Indonesia Nomor 71 Tahun 2010 tentang Standar Akuntansi Pemerintah.

Peraturan Menteri Dalam Negeri Nomor 64 Tahun 2013 tentang Penerapan Standar Akuntansi Pemerintahan Berbasis Akrual Pada Pemerintah Daerah.

Peraturan Menteri Dalam Negeri Nomor 17 Tahun 2007 tentang Pedoman Teknis Pengelolaan Barang Milik Daerah.

Suwanda, D. (2013). Strategi Mendapatkan Opini UNQUALIFIED OPINION Laporan Keuangan Pemda. Edisi Kedua. Jakarta: PPM Manajemen.

Tobing, R. dan Nirwana. (2004). Kamus Istilah Akuntansi. Jakarta: Penerbit PT. Atalya Rileni Sudeco.

Undang-Undang Republik Indonesia Nomor 17 Tahun 2003 tentang Keuangan Negara.

Undang-Undang Republik Indonesia Nomor 1 Tahun 2004 tentang Perbendaharaan Negara.

Undang-Undang Republik Indonesia Nomor 15 Tahun 2004 tentang Pemeriksaan Pengelolaan dan Tanggung Jawab Keuangan Negara. 